\title{
Sincere Cooperation in the Common Commercial Policy: Lisbon, a "Joined-Up" Union, and "Brexit"
}

\author{
Joris Larik
}

\begin{abstract}
The article elaborates on the significance of the duty of sincere cooperation as a legal principle in the Common Commercial Policy (CCP) of the European Union (EU), in particular as regards the relationship between the Union and its Member States. It argues that while the duty of sincere cooperation is a judicially enforceable duty vis-à-vis the Member States, it is losing some of its relevance in the context of the CCP. This is due to the fact that the Lisbon Treaty, as confirmed by the case law of the Court of Justice of the EU, expanded the scope of the CCP and clearly identifies it as an exclusive competence of the Union. Loyalty in the $\mathrm{CCP}$, therefore, is mainly covered by the obligation to respect the exclusivity of the Union's international powers in this area. While this does not equate to the disappearance of the Member States as actors in international economic governance, it does seriously constrain their leeway for autonomous action. In addition, the article applies this finding to a number of current developments surrounding the CCP. These include, firstly, the new Global Strategy for Foreign and Security Policy, which promotes the idea of a "joined-up" approach between different actors and policies; secondly, "Brexit" and the prospect of the United Kingdom negotiating new trade agreements of its own; thirdly, the position of the Member States in the WTO; and fourthly, the nature of the wave of new free trade agreements that the EU is negotiating and concluding.
\end{abstract}

\section{Contents}

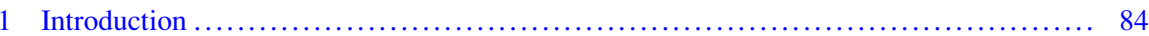

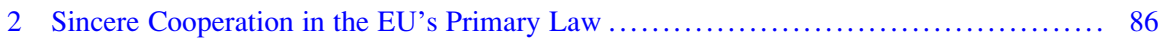

3 Case Law on Loyalty in EU External Action $\ldots \ldots \ldots \ldots \ldots \ldots \ldots \ldots \ldots \ldots \ldots \ldots \ldots \ldots . \ldots 8$

3.1 Sincere Cooperation in the Negotiation of International Agreements ........... 89

3.2 Member States Acting in the Union's Interest .......................... 90

3.3 Sincere Cooperation in "Mixed" Agreements ........................... 91

3.4 Sincere Cooperation as a "Duty to Remain Silent" in International Bodies ....... 92

\footnotetext{
J. Larik $(\bowtie)$

Faculty of Governance and Global Affairs, Leiden University, Anna van Buerenplein 301, 3595 DG The Hague, The Netherlands

e-mail: j.e.1arik@luc.leidenuniv.nl
} 
4 Sincere Cooperation in the Common Commercial Policy ......................... 94

4.1 The Widened Scope and Exclusive Nature of the Common Commercial Policy ... 94

4.2 The Diminished Relevance of the Duty of Sincere Cooperation ................ 97

5 Outlook: The EU's Global Strategy, "Brexit", the WTO, and New Free Trade

Agreements ........................................................ 99

5.1 The Common Commercial Policy and the Global Strategy for Foreign and Security

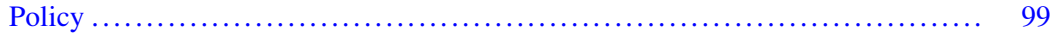

5.2 "Brexit" and Sincere Cooperation of the EU27 ............................ 102

5.3 Continued WTO Membership of the Member States ........................ 105

5.4 Mixity and Cooperation in the New Free Trade Agreements .................. 106

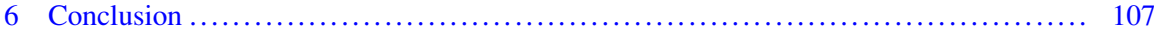

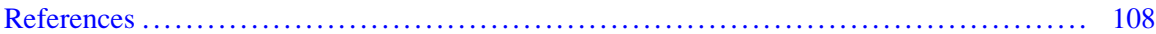

\section{Introduction}

The Common Commercial Policy (CCP) of the European Union (EU) is arguably the most unequivocal manifestation of the Union as a power in international affairs and global governance. ${ }^{1}$ Based on one of the world's largest markets, the Union pursues both trade-specific and other foreign policy goals on the global stage. ${ }^{2}$ Inverting the order of the well-known quote by former Belgian Foreign Minister Mark Eyskens, next to the EU's "military worm" and "political dwarf", the "economic giant" still looms large. ${ }^{3}$ Even "Brexit" will not change that, as without the United Kingdom (UK), the EU would still be the second largest economic bloc in the world, after the United States. ${ }^{4}$

In addition to pursuing traditional trade-related objectives that are enshrined in law since the Treaty of Rome, ${ }^{5}$ which, among other things, call on the EU to contribute to "the harmonious development of world trade" and "the progressive abolition of restrictions on international trade", 7 the CCP also serves as an instrument for pursuing a more ambitious, normative global agenda. This includes aspirations such as to "consolidate and support democracy, the rule of law, human rights and the principles of international law", ${ }_{8}^{8}$ to promote "the sustainable development of the Earth", 9 and to bring about "an international system based on stronger multilateral cooperation and good global governance."10 These objectives

\footnotetext{
${ }^{1}$ Meunier and Nicolaïdis (2011).

${ }^{2}$ Larik (2011), pp. 23-34.

${ }^{3}$ Minister Eyskens in 1990 noted that the European Community was "an economic giant, a political dwarf, and a military worm". Quoted in McCormick (2008), p. 192.

${ }^{4}$ See statistics on Gross Domestic Product (GDP) from the World Bank, GDP (current US\$), http:// data.worldbank.org/indicator/NY.GDP.MKTP.CD (last accessed 1 March 2017).

${ }^{5}$ Article 110 Treaty Establishing the European Economic Community (original version of 1957).

${ }^{6}$ Article 206 Treaty on the Functioning of the European Union (TFEU).

${ }^{7}$ Article 21(2) lit. e Treaty on European Union (TEU).

${ }^{8}$ Article 21(2) lit. b TEU.

${ }^{9}$ Article 3(5) TEU.

${ }^{10}$ Article 21(2) lit. h TEU.
} 
serve as the substantive constitutional foundation for the CCP in the post-Lisbon era. They inform the implementation of trade and foreign policy of the EU, as expressed, for instance, in the Trade for All strategy of October $2015^{11}$ and the Global Strategy for Foreign and Security Policy, ${ }^{12}$ which was presented to the European Council in June 2016. ${ }^{13}$

Such an ambitious, codified mandate raises the question of which actors should realize all of this. Despite the CCP being an "exclusive" competence of the EU, ${ }^{14}$ this does not only concern the EU institutions, ${ }^{15}$ but also its 28 (or 27, post"Brexit") Member States. These are represented, in addition to the Union, at the World Trade Organization (WTO) as full members, ${ }^{16}$ and are, alongside the Union, parties to a range of comprehensive trade agreements with third countries around the world. ${ }^{17}$ The Member States, and their respective parliaments, continue to stake their claim to exercise their rights in this external policy area. ${ }^{18}$

Therefore, in addition to economic power and ambitions in the area of global governance, the parallelism — or "polyphony"19_of EU institutions and Member States on the international stage remains one of the defining features of the CCP. To ensure that polyphony does not result in cacophony and that the EU's economic weight can be effectively leveraged in the pursuit of its aspirations, the duty of sincere cooperation plays a crucial role. This principle is enshrined in primary law as well. In relation to the Member States it is found in Article 4(3) TEU.

The duty of sincere cooperation has received sustained attention in the scholarly literature. ${ }^{20}$ Precisely because of the "polyphony" in EU external relations, particular attention is paid to its importance in the external action of the Union and the collective implementation of mixed agreements (i.e. agreements with third countries or organizations to which both Union and Member States are parties). ${ }^{21}$

\footnotetext{
${ }^{11}$ European Commission, Trade for All: Towards a More Responsible Trade and Investment Policy, COM (2015) 497 final, Brussels, 14 October 2015; see previously European Commission, Global Europe: Competing in the World: A Contribution to the EU's Growth and Jobs Strategy, COM (2006) 567 final, Brussels, 4 October 2006.

${ }^{12}$ Shared Vision, Common Action: A Stronger Europe, A Global Strategy for the European Union's Foreign and Security Policy, June 2016.

${ }^{13}$ European Council, Conclusions, EUCO 26/16, Brussels, 28 June 2016, para. 20.

${ }^{14}$ Article 3(1) lit. e TFEU.

${ }^{15}$ See Dederer (2013).

${ }^{16}$ Article XI:1 Agreement Establishing the World Trade Organization.

${ }^{17}$ See, for instance, the Free trade Agreement between the European Union and its Member States, of the one part, and the Republic of Korea, of the other part, OJ 2011 L 127/6.

${ }^{18}$ See the reply of the European Commission to an opinion issued by 20 parliaments of the Member States, Maroš Šef̌covič, Vice-President of the European Commission, Brussels, 16 October 2014, C (2014) 7557 final.

${ }^{19}$ Hillion (2010), p. 87.

${ }^{20}$ See De Baere and Roes (2015); Klamert (2014); Hatje (2001); Hyett (2000).

${ }^{21}$ Klamert (2014), p. 183 et seq.; Delgado Casteleiro and Larik (2011); Neframi (2010); Hillion (2010); Kaiser (2009), p. 47 et seq.; Heliskoski (2001), p. 46 et seq.
} 
It is clear that both the orchestration of harmony among these actors and the surrounding "soundscape" are in transition, being drawn in different directions by six main legal and political developments. These are, firstly, the amendments introduced by the Lisbon Treaty, which entered into force in 2009 and which led to important changes to the $\mathrm{CCP}$ and the EU's system of external relations as a whole; secondly, the recent case law of the Court of Justice of the EU (CJEU), which is in the process of clarifying the new legal situation post-Lisbon; thirdly, the revamping of EU trade and foreign policy through the adoption of a new comprehensive strategy document; fourthly, the consequences of the EU membership referendum in the United Kingdom of June 2016 and the prospect of the UK leaving the Union over the next years; fifthly, the evolving external representation of the EU and its Member States at the WTO; and sixthly, the negotiation of a range of new, deep and comprehensive (and often controversial) trade agreements.

Against this backdrop, the objective of this article is to contribute to a better understanding of "harmony" in the complex interplay of actors and norms in the $\mathrm{CCP}$ in light of these developments. The argument put forward here affirms, on the one hand, the continuing importance of sincere cooperation as a legal principle in the external relations of the EU in general, and as regards the use of trade policy in implementing the Global Strategy and its "joined-up" approach in particular. On the other hand, it posits that in the area of the CCP proper, loyalty as a legal principle is losing some of its relevance due to both practical factors and the judicially sanctioned transfer of powers in favour of the Union. The article furthermore outlines the main consequences of "Brexit" in this area. Overall, "polyphony" and mixed agreements will continue to characterize the CCP. Therefore, the duty of sincere cooperation will remain an important legal principle also in the $\mathrm{CCP}$ though not the most important one by any measure.

\section{Sincere Cooperation in the EU's Primary Law}

Sincere cooperation is not only a core legal principle within the EU legal order, but can be described more accurately as a principle of European composite constitutional law, as it applies not only to relations between the EU institutions, ${ }^{22}$ but also in the mutual relations between the Union and its Member States. This application extends to the foreign relations of the Member States and the EU. It is this latter aspect which gives a special significance to it, since both the EU and the Member States remain active on the world stage. The principle is stipulated in Article 4(3) TEU, as amended by the Lisbon Treaty:

Pursuant to the principle of sincere cooperation, the Union and the Member States shall, in full mutual respect, assist each other in carrying out tasks which flow from the Treaties.

${ }^{22}$ Article 13(2) TEU. 
The Member States shall take any appropriate measure, general or particular, to ensure fulfilment of the obligations arising out of the Treaties or resulting from the acts of the institutions of the Union.

The Member States shall facilitate the achievement of the Union's tasks and refrain from any measure which could jeopardise the attainment of the Union's objectives. ${ }^{23}$

This provision follows directly after the call on the EU to respect the Member States' "national identities, inherent in their fundamental structures, political and constitutional". ${ }^{24}$ Primacy of EU law and its full and effective implementation in the domestic legal order can be regarded as one of the foremost expressions of loyal cooperation. ${ }^{25}$ However, as the recent case law of Member States' constitutional courts shows, loyalty can reach its limits where the core of constitutional identity starts. ${ }^{26}$ Sincere cooperation is not to be understood as a duty of blind obedience for the Member States. At the same time, the structure of the TEU also suggests that the duty of sincere cooperation is fully applicable to any Member State actions that fall outside the narrow confines of "constitutional identity" to be guarded by national supreme or constitutional courts in the Member States.

Moreover, sincere cooperation is not to be understood as an end in itself, but as an inherently goal-oriented concept. This is clear from the obligations of Member States to "facilitate the achievement of the Union's tasks" and to "refrain from any measure which could jeopardise the attainment of the Union's objectives". These objectives are more extensive than ever in the EU Treaties post-Lisbon, ${ }^{27}$ and represent a kaleidoscope of dimensions of the "common good" of the Union, rather than a catalogue of specific functions. ${ }^{28}$

In addition to this general formulation of the principle of sincere cooperation, it is also enshrined in other parts of the Treaties, applied to specific policies and actors. In the area of the Common Foreign and Security Policy (CFSP), it finds a rather eloquent expression. After evoking "the development of mutual political solidarity among Member States" and "the achievement of an ever-increasing degree of convergence of Member States' actions", ${ }^{29}$ the following paragraph provides that:

\footnotetext{
${ }^{23}$ Article 4(3) TEU.

${ }^{24}$ Article 4(2) TEU; see seminally Millet (2013).

${ }^{25}$ See from the more recent case law of the CJEU, opinion 2/13, ECHR, ECLI:EU:C:2014:2454, para. 173; CJEU, case C-66/13, Green Network, ECLI:EU:C:2014:2399, para. 7; CJEU, case C-41/11, Inter-Environnement Wallonie, ECLI:EU:C:2012:103, para. 43.

${ }^{26}$ See the judgment of the German Federal Constitutional Court (Second Senate) of 15 December 2015, 2 BvR 2735/14, paras. 40-50, where explicit reference is made to Article 4(3) and Article 4(2) TEU.

${ }^{27}$ See first and foremost Article 3(1) TEU, which declares the promotion of peace, the Union's values and the well-being of its people to be objectives of the EU. Also with specific regard to the EU's external action, there is no shortage of broadly defined ambitions, see Articles 3(5) and 21 TEU.

${ }^{28}$ See Piris (2010), p. 73.

${ }^{29}$ Article 24(2) TEU.
} 
The Member States shall support the Union's external and security policy actively and unreservedly in a spirit of loyalty and mutual solidarity and shall comply with the Union's action in this area.

The Member States shall work together to enhance and develop their mutual political solidarity. They shall refrain from any action which is contrary to the interests of the Union or likely to impair its effectiveness as a cohesive force in international relations.

The Council and the High Representative shall ensure compliance with these principles. ${ }^{30}$

The same spirit is clearly present also in the EU's Global Strategy for Foreign and Security Policy, which notes that "EU foreign policy is not a solo performance: it is an orchestra which plays from the same score." 31

This should not hide the fact that the justiciability of the principle of sincere cooperation in the area of the CFSP is highly restricted-if not denied-due to the limited jurisdiction of the CJEU. ${ }^{32}$ The use of the word "political solidarity" suggests that in this case loyalty is not to be understood as a judicially enforceable duty. Lastly, also the mutual assistance clause in the event of armed aggression ${ }^{33}$ and the solidarity clause in case of terrorist attacks and disasters ${ }^{34}$ can be considered as manifestations of sincere cooperation laid down in the primary law. As part of the CCP, a duty of loyal cooperation is not specifically repeated. Here, therefore, the general principle enshrined in Article 4(3) TEU, which covers all policy areas, applies.

\section{Case Law on Loyalty in EU External Action}

The programmatic and open wording in the formulation of the principle of sincere cooperation in Article 4(3) TEU notwithstanding, it is a justiciable legal principle that applies both to internal and external action, and to the relationship both between the Member States inter se and in the relationship between the EU and

\footnotetext{
${ }^{30}$ Article 24(3) TEU.

${ }^{31}$ Shared Vision, Common Action: A Stronger Europe, A Global Strategy for the European Union's Foreign and Security Policy, June 2016, p. 46.

${ }^{32}$ Article 24(1) subpara. 2 TEU, read in conjunction with Article 40 TEU and Article 275(2) TFEU. See further on the "bipolarity" between CFSP and other EU policies, Dashwood (2014). But see, for an argument to extend the duty of sincere cooperation into the CFSP, Hillion (2014), p. 67.

${ }^{33}$ Article 42(7) TEU. This provision, and not the one on mutual solidarity enshrined in Article 222 TFEU, was invoked for the first time in December 2015 by the French government following the terrorist attacks in Paris, see Council of the European Union, Outcome of the Council Meeting, 3426th Council meeting, Foreign Affairs, Brussels, 16 and 17 November 2015, 14,120/15 (OR en), Presse 69, PR CO 61, p. 6.

${ }^{34}$ Article 222 TFEU.
} 
Member States. ${ }^{35}$ With regard to the case law of the CJEU in relation to Union loyalty in the external relations of the EU, one can distinguish a number of different legal effects. These effects, several of which can apply at the same time, become evident in four main situations. Firstly, in addition to a general interpretive component, ${ }^{36}$ there exist both positive, optimizing duties to act as well as duties of abstention for the Member States when it comes to the negotiation of international agreements. Secondly, there are specific situations in which the Member States are obliged to act jointly in the Union's interest in international organizations. Thirdly, the duty of sincere cooperation plays a particularly important role in the implementation of mixed agreements. Fourthly, sincere cooperation can amount to a duty for Member States to refrain from acting altogether in international bodies if this undermines Union positions, both in areas of exclusive and shared competence.

As a preliminary observation, it should be noted that the CJEU derives from the principle of sincere cooperation also a "principle of unity in the international representation of the Union and its Member States". ${ }^{37}$ However, rather than being an independent legal principle, it is to be understood as an expression of sincere cooperation on the international stage. ${ }^{38}$

\subsection{Sincere Cooperation in the Negotiation of International Agreements}

The negative and positive dimensions of sincere cooperation became clearly visible in CJEU judgments of 2005 on the signing and ratification of agreements between Member States and third countries concerning inland waterway transport. These actions were considered unlawful in light of the loyalty obligations towards the former European Community because the Commission was conducting negotiations on the same subject with the same third countries. In the judgment, the Court stated:

\footnotetext{
${ }^{35}$ From the recent case law in the context of internal EU policies see, for example, CJEU, case C-515/14, Commission v. Cyprus, ECLI:EU:C:2016:30; CJEU, case C-408/14, Aliny Wojciechowski v. Office national des pensions (ONP), ECLI:EU:C:2015:591. See also the CJEU, opinion 2/13, ECHR, ECLI:EU:C:2014:2454, para. 173; CJEU, case C-66/13, Green Network, ECLI:EU:C:2014:2399, para. 7; CJEU, case C-41/11, Inter-Environnement Wallonie, ECLI:EU:C:2012:103, para. 43.

${ }^{36}$ See, for instance, CJEU, case C-308/06, Intertanko, ECLI:EU:C:2008:312, para. 52, where the CJEU found that in "view of the customary principle of good faith, which forms part of general international law, and of Article 10 EC [now Article 4(3) TEU], it is incumbent upon the Court to interpret" secondary Union legislation in a way that takes into account international legal rules which are binding on the Member States, but not the Union.

${ }^{37}$ CJEU, case C-246/07, Commission v. Sweden (PFOS), ECLI:EU:C:2010:203, para. 104; and CJEU, opinion 2/91, ILO, ECLI:EU:C:1993:106, para. 36. See further Thies (2012), p. 721.

${ }^{38}$ See the Opinion of Advocate General Poiares Maduro, CJEU, case C-246/07, Commission v. Sweden (PFOS), ECLI:EU:C:2009:589, para. 37.
} 
The adoption of a decision authorising the Commission to negotiate a multilateral agreement on behalf of the Community marks the start of a concerted Community action at international level and requires for that purpose, if not a duty of abstention on the part of the Member States, at the very least a duty of close cooperation between the latter and the Community institutions in order to facilitate the achievement of the Community tasks and to ensure the coherence and consistency of the action and its international representation $[\ldots]^{39}$

As one of the expressions of sincere cooperation, the CJEU admonished that the Member State governments should have coordinated better with the Commission. From that case it is evident that positive duties as part of sincere cooperation include an active information policy and regular consultations. ${ }^{40}$

The CJEU accords an independent status to the positive duty to provide information as an expression of Union loyalty in the external action of the Member States, ${ }^{41}$ at least as long as this is not covered by specific requirements on information exchange in the Treaties. ${ }^{42}$ This has to be distinguished from the question whether sharing information in a more timely and extensive fashion by Member States could justify certain, otherwise "disloyal" acts on the international scene. In the above case on inland waterway transport, while the Court noted information and consultation duties, the finding of unlawful conduct was based on the signature and ratification by the Member States of the agreements with third countries. ${ }^{43}$ It remains doubtful that the Member States' infringement could have been remedied by them having more intensively consulted with the Commission in any way.

\subsection{Member States Acting in the Union's Interest}

In addition, the duty of sincere cooperation applies in situations in which the Union cannot represent itself in an international setting. The reason for this is that many international treaties and organizations allow only States-still considered the

\footnotetext{
${ }^{39} \mathrm{CJEU}$, case C-433/03, Commission v. Germany (Inland Waterways), ECLI:EU:C:2005:462, para. 66; CJEU, case C-266/03, Commission v. Luxembourg (Inland Waterways), ECLI:EU: C:2005:341, para. 60 .

${ }^{40} \mathrm{CJEU}$, case C-433/03, Commission v. Germany (Inland Waterways), ECLI:EU:C:2005:462, paras. 68-70; see also CJEU, case C-459/03, Commission v. Ireland (Mox Plant), ECLI:EU: C:2006:345, paras. 179-181.

${ }^{41} \mathrm{CJEU}$, case C-459/03, Commission v. Ireland (Mox Plant), ECLI:EU:C:2006:345, paras. 173-181.

${ }^{42}$ See CJEU, case C-658/11, Parliament v. Council (Mauritius Pirate Transfer Agreement), ECLI: EU:C:2014:2025, in which the CJEU found the Council had violated the European Parliament's right to be informed, as enshrined in Article 218(10) TFEU, which is specifically about the negotiation and conclusion of international agreements, including those which fall primarily into the CFSP. Article 4(3) TEU was not mentioned in this case.

${ }^{43} \mathrm{CJEU}$, case C-433/03, Commission v. Germany (Inland Waterways), ECLI:EU:C:2005:462, para. 73 .
} 
"normal" subjects of international law ${ }^{44}$ - to acquire full party status or membership, including the right to vote. ${ }^{45}$

In such cases, the principle of sincere cooperation obliges the Member States to actively help the Union to ensure that its competences can nonetheless be exercised, and its objectives can be pursued internationally. In the words of the Court, the external competences of the EU should "be exercised through the medium of the Member States acting jointly in the [then] Community's interest." ${ }^{46}$ The Member States thus become in these cases international "trustees" of the Union interest. ${ }^{47}$ This can lead to situations in which a Member State has to defend a position in a multilateral forum, as soon as it is to be regarded as genuine Union position. This duty applies even if the agreement setting up that forum has not been concluded by the Union and even if the government of the Member State in question disagrees with the position and voted against its adoption within the Council. ${ }^{48}$

\subsection{Sincere Cooperation in "Mixed" Agreements}

Of particular importance with regard to sincere cooperation are so-called mixed agreements. Due to competences being shared between Union and Member States, which is also expressed externally by the parallel presence of Union and Member States on the international scene, the requirements of a "unity of international representation" and "close cooperation" between them become all the more relevant. ${ }^{49}$ From this consideration, the Court later derived also an obligation of the Member States towards the Union to fully implement mixed agreements, including in areas not covered by EU competence. ${ }^{50}$

In more recent case law, the CJEU has noted, furthermore, that the adoption of so-called "hybrid decisions" to conclude an international agreement, i.e. decisions "by both the Council and the Representatives of the Governments of the Member

\footnotetext{
${ }^{44}$ Epping (2014), p. 49.

${ }^{45}$ See Wouters et al. (2016); Hoffmeister and Kuijper (2006); Govaere et al. (2004).

${ }^{46} \mathrm{CJEU}$, opinion 2/91, ILO, ECLI:EU:C:1993:106, para. 5; see also CJEU, case C-45/07, Commission v Greece (IMO), ECLI:EU:C:2009:81, para. 31.

${ }^{47}$ Cremona (2011).

${ }^{48}$ CJEU, case C-399/12, Germany v. Council (OIV), ECLI:EU:C:2014:2258. This case concerned the applicability of Article 218(9) TFEU to the establishment of a common EU position within the International Organisation of Vine and Wine (OIV). The CJEU confirmed the applicability of this provision, but did not make reference to Article 4(3) TEU. See further Govaere (2014).

${ }^{49}$ CJEU, opinion 1/94, WTO, ECLI:EU:C:1994:384, para. 108.

${ }^{50} \mathrm{CJEU}$, case C-13/00, Commission v. Ireland (Berne Convention), ECLI:EU:C:2002:184; CJEU, case C-239/03, Commission v. France (Étang de Berre), ECLI:EU:C:2004:598.
} 
States meeting within the Council", 51 violates inter-institutional loyalty duties, even if the mixed nature of the agreement is not in dispute. ${ }^{52}$

\subsection{Sincere Cooperation as a "Duty to Remain Silent" in International Bodies}

Moreover, the duty of sincere cooperation may oblige Member States to refrain from certain autonomous actions within international bodies or fora, both in areas of exclusive and shared Union competence.

With regard to the former, a Member State is barred from autonomously submitting proposals to bodies of international organizations when their substance falls within the exclusive competence of the Union. The "ERTA doctrine" 53 hence applies also to these situations because a proposal unilaterally introduced by Member States can, in the eyes of the CJEU, set in motion "a procedure which could lead to the adoption" of new rules on the international plane with legal ramification for the Union. ${ }^{54}$ Sincere cooperation in external action therefore starts for the Member States not only with unambiguous international legal acts, but much earlier, i.e. at the stage of discussing and preparing new rules within international fora.

The CJEU also notes that Member States must refrain from the above mentioned actions, even if they have previously tried in vain to put their concerns on the agenda within the EU institutions, and even if this was thwarted by possibly disloyal behaviour on the part of the European Commission. Although the Commission, when chairing the relevant committees, "may not prevent such an exchange of views on the sole ground that a proposal is of a national nature", 55 nonetheless any breach by the Commission of its loyalty obligations "cannot entitle a Member State to take initiatives likely to affect Community rules promulgated for the attainment of the objectives of the Treaty". 56 As it is unclear how this potentially disloyal Commission action could be addressed by the Member State, a certain asymmetry becomes apparent in the scope and the enforceability of the duty of sincere cooperation between Union institutions and Member States in the area of external relations. ${ }^{57}$ In any event, it is reasonable to conclude that such a

\footnotetext{
${ }^{51}$ CJEU, case C-28/12, Commission v. Council (U.S. Air Transport Agreement), ECLI: EU: C:2015:282, para. 6 .

${ }^{52} \mathrm{CJEU}$, case C-28/12, Commission v. Council (U.S. Air Transport Agreement), ECLI:EU: C:2015:282, para. 53, where the CJEU found a violation of Article 13(2) TEU.

${ }^{53}$ The doctrine originated in CJEU, case 22/70, Commission v Council (ERTA), ECLI:EU: C:1971:32.

${ }^{54}$ CJEU, case C-45/07, Commission v Greece (IMO), ECLI:EU:C:2009:81, para. 21.

${ }^{55} \mathrm{CJEU}$, case C-45/07, Commission v Greece (IMO), ECLI:EU:C:2009:81, para. 25.

${ }^{56} \mathrm{CJEU}$, case C-45/07, Commission v Greece (IMO), ECLI:EU:C:2009:81, para. 26.

${ }^{57}$ See Cremona (2009), p. 765 et seq.
} 
breach of the duty by virtue of an external act could not be justified through (even) better communication or consultation with the Union institutions.

Such extensive loyalty obligations of the Member States at the international level do not only apply in areas of exclusive EU competence, but also where Union and Member States share competence in cases where a concerted, internally developed Union position is discernible. Hence, if a Member State departs from such positions in areas of shared competences, this amounts to a violation of its duty of sincere cooperation as well. The CJEU has emphasized that the "duty of genuine cooperation is of general application and does not depend either on whether the Community competence concerned is exclusive or on any right of the Member States to enter into obligations towards non-member countries". ${ }^{8}$ Furthermore, a "point of departure for concerted Community action" can be assumed to exist as soon as the Commission has made a proposal to the Council, even if it has not been accepted (yet), ${ }^{59}$ and regardless of the form it takes "provided that the content of that position can be established to the requisite legal standard". 60

Hence, if a Member State submits certain proposals in international fora, which deviate from the Union's position and which can start processes that may lead to producing binding legal effects for the EU, a situation arises that is "likely to compromise the principle of unity in the international representation of the Union and its Member States and weaken their negotiating power with regard to" third parties. ${ }^{61}$ Even when the adoption of certain decisions is postponed within the Union's institutions, the Court does not consider this a "decision-making vacuum", but still as a legitimate part a common strategy. ${ }^{62}$

The existence of shared competence does not diminish the negative obligation prohibiting Member States from undermining in any way such a "strategy" by acting internationally. Moreover, the Member States do not get back the freedom to become active internationally after a certain waiting period-even if such activities fall within their own competence. Advocate General Poiares Maduro had noted that the disloyally acting Member State should continue to try to participate in the Union's internal decision-making process "even if, politically, it felt that its efforts to achieve a common proposal [...] were as doomed as lemmings heading towards the edge of a cliff."63 Also then, the Member States remain trustees of the Union interest.

In addition, further manifestations of disloyal external action become apparent from the CJEU's case law. Firstly, the Member States are prohibited from availing

\footnotetext{
${ }^{58}$ CJEU, case C-246/07, Commission v. Sweden (PFOS), ECLI:EU:C:2010:203, para. 71; see also De Baere (2011).

${ }^{59} \mathrm{CJEU}$, case C-246/07, Commission v. Sweden (PFOS), ECLI:EU:C:2010:203, para. 74.

${ }^{60} \mathrm{CJEU}$, case C-246/07, Commission v. Sweden (PFOS), ECLI:EU:C:2010:203, para. 77.

${ }^{61}$ CJEU, case C-246/07, Commission v. Sweden (PFOS), ECLI:EU:C:2010:203, para. 104.

${ }^{62} \mathrm{CJEU}$, case C-246/07, Commission v. Sweden (PFOS), ECLI:EU:C:2010:203, para. 87.

${ }^{63}$ Opinion of AG Poiares Maduro to CJEU, case C-246/07, Commission v. Sweden (PFOS), ECLI: EU:C:2009:589, para. 58.
} 
themselves of international dispute settlement mechanisms, insofar as this endangers the exclusive jurisdiction of the CJEU. ${ }^{64}$ When it comes to matters of EU law, the Member States can speak up at the Court of Justice in Luxembourg, but not at other venues.

In sum, two main points stand out from the CJEU's case law on the external action of the Union and the Member States. On the one hand, the Court has repeatedly stressed the importance of the duty of sincere cooperation in this context. Precisely because of the polyphony, complexity, and-from the perspective of traditional international law-peculiarity of the Union as an international actor, special efforts to maintain unity and ensure close cooperation are required. On the other hand, and without prejudice to the emphasis which the Treaties and the CJEU put on the general applicability of Union loyalty, the duty manifests itself as a justiciable principle - as far as it does not concern the CFSP or the core of national or constitutional identity-mainly as a "duty to remain silent" 65 incumbent upon the Member States on the international stage. The rationale of this manifestation of sincere cooperation is preventing Union strategies and positions from being undermined by autonomous national action taken outside of the EU framework.

\section{Sincere Cooperation in the Common Commercial Policy}

As regards the CCP in particular, sincere cooperation is certainly a legally significant duty also in this policy area. However, it is likely-though this may sound paradoxical-that precisely because of the expanded scope of the CCP after the Lisbon reform as an exclusive EU competence, sincere cooperation will lose some of its relevance as a legal principle.

\subsection{The Widened Scope and Exclusive Nature of the Common Commercial Policy}

The competences of the EU in the CCP have been expanded by the Lisbon Treaty, which now include also trade in services, trade-related aspects of intellectual property, and foreign direct investment as integral components. ${ }^{66}$ Moreover, the

\footnotetext{
${ }^{64}$ Here, Article 344 TFEU (formerly Article 292 of the Treaty Establishing the European Community (TEC)) has to be "understood as a specific expression of Member States' more general duty of loyalty", CJEU, case C-459/03, Commission v. Ireland (Mox Plant), ECLI:EU:C:2006:345, para. 169; see also CJEU, opinion 2/13, ECHR, ECLI:EU:C:2014:2454, para. 202.

${ }^{65}$ Delgado Casteleiro and Larik (2011).

${ }^{66}$ Article 207(1) TFEU. However, for these three areas special procedures apply, which deviate from qualified majority voting, according to Article 207(4) subpara. 2 TFEU.
} 
Lisbon reform enshrined more clearly and extensively than before the pursuit of both trade-related and other objectives in the area of global governance through the CCP in the primary law. ${ }^{67}$ In the TFEU, specific trade objectives are still present in the form of the call to "contribute, in the common interest, to the harmonious development of world trade, the progressive abolition of restrictions on international trade and on foreign direct investment, and the lowering of customs and other barriers. ${ }^{" 68}$ In addition, trade policy objectives have been included in the catalogue of general objectives of EU external action, in the form of a commitment to "free and fair trade" $" 69$ and the pledge to "encourage the integration of all countries into the world economy, including through the progressive abolition of restrictions on international trade" ${ }^{70}$

At the same time, a reference is made in the section on the CCP in the TFEU to the general canon of external relations objectives. Accordingly, the CCP "shall be conducted in the context of the principles and objectives of the Union's external action". ${ }^{71}$ All objectives of the Union, also in the relationship between internal and external policies, are to be pursued in a coherent manner. ${ }^{72}$ The codification in the primary law of the EU's geopolitical ambitions and the integration of the objectives of the CCP therein needs to be taken into account with regard to the interpretation and application of the duty of sincere cooperation. As shown above, it imposes on the Member States the obligation, which can be adjudged by the CJEU, to refrain from actions "which could jeopardise the attainment of the Union's objectives."73

Furthermore, the duty of sincere cooperation assumes an especially important position within the CCP since both the WTO agreements as well as the new generation of deep and comprehensive trade agreements following the "Global Europe" strategy ${ }^{74}$ are mixed agreements. ${ }^{75}$ Already in opinion $1 / 94$, which concerned the extent of the competences of the former Community regarding the

\footnotetext{
${ }^{67}$ See Larik (2015a), p. 52 et seq.

${ }^{68}$ Article 206 TFEU.

${ }^{69}$ Article 3(5) TEU.

${ }^{70}$ Article 21(2) lit. e TEU.

${ }^{71}$ Article 207(1) TFEU; see Vedder (2013) and Dimopoulos (2010).

${ }^{72}$ Article 21(3) subpara. 2 TEU; as well as Article 13(1) TEU; see extensively on this issue Engbrink (2014); and also Larik (2016), p. 175 et seq.

${ }^{73}$ Article 4(3) subpara. 2 TEU.

${ }^{74}$ See European Commission, Global Europe: Competing in the World: A Contribution to the EU's Growth and Jobs Strategy, COM (2006) 567 final, Brussels, 4 October 2006, pp. 10-12 on trade agreements.

${ }^{75}$ See, for example, the Free trade Agreement between the European Union and its Member States, of the one part, and the Republic of Korea, of the other part, OJ 2011 L 127/6; the "mixed" Economic Partnerships Agreements with African, Caribbean and Pacific states, such as the Economic Partnership Agreement between the CARIFORUM States, of the one part, and the European Community and its Member States, of the other part, OJ 2008 L 289/3; and the Association Agreement between the European Union and the European Atomic Energy Community and their Member States, of the one part, and Georgia, of the other part, OJ 2014 L 261/4, especially Article 22 et seq. on the establishment of a free trade area.
} 
conclusion of the WTO agreements, the CJEU stressed "the requirement of unity in the international representation" and the need for "close cooperation between the Member States and the Community institutions, both in the process of negotiation and conclusion and in the fulfilment of the commitments entered into"76 in mixed agreements. Furthermore, the Court emphasized that specifically in the context of the WTO the "duty to cooperate is all the more imperative in the case of agreements such as those annexed to the Agreement establishing the World Trade Organization, which are inextricably interlinked, and in respect of which a dispute settlement system is established involving cross-retaliation measures." 77

These findings certainly remain true today. However, with regard to the relevance of the duty of sincere cooperation as a legal principle in litigation and in the development of the law by the CJEU, some qualifications need to be borne in mind.

Traditionally, the CCP was not a shared but an exclusive competence of the former Community, which was interpreted to be broad in scope by the CJEU. ${ }^{78}$ During a period that from today's perspective we need to understand as an interlude, starting with the creation of the WTO and the Treaty of Maastricht, the CCP became an intricately organized, shared competence. ${ }^{79}$ During this period, the EU institutions repeatedly questioned the boundaries and nature of competences within the CCP in cases before the CJEU. ${ }^{80}$ In a setting which is characterized by such complexity and fluidity, practicing sincere cooperation between the Union and Member States undoubtedly became all the more imperative.

However, with the entry into force of the Lisbon Treaty and seeing the recent CJEU case law, this interlude is coming to an end as today the CCP clearly falls within the exclusive competence of the EU as a whole again. In a catalogue of competences laid down in the TFEU, the CCP is explicitly listed as an exclusive Union competence. ${ }^{81}$ This entails that "only the Union may legislate and adopt legally binding acts, the Member States being able to do so themselves only if so empowered by the Union or for the implementation of Union acts." ${ }^{82}$

The exclusive nature of the CCP was confirmed by the CJEU also concerning its scope as defined after the Lisbon reform, especially as regards former "grey areas" such as trade-related aspects of intellectual property rights and trade in services in

\footnotetext{
${ }^{76}$ CJEU, opinion 1/94, WTO, ECLI:EU:C:1994:384, para. 19.

${ }^{77}$ CJEU, opinion 1/94, WTO, ECLI:EU:C:1994:384, para. 19.

${ }^{78} \mathrm{CJEU}$, opinion 1/75, Local Cost Standard, ECLI:EU:C:1975:145; and CJEU, case 45/86, Commission v. Council (Generalized Tariff Preferences), ECLI:EU:C:1987:163; see further Koutrakos (2015), pp. 17-74.

${ }^{79}$ Article 133 TEC; see also Herrmann (2002).

${ }^{80} \mathrm{CJEU}$, case C-53/96, Hermès International, ECLI:EU:C:1998:292; CJEU, joined cases C-300/ 98 and C-392/98, Dior, ECLI:EU:C:2000:688; CJEU, case C-431/05, Merck Genéricos, ECLI: EU:C:2007:496; CJEU, opinion 1/08, GATS, ECLI:EU:C:2009:739; see further Hoffmeister (2013), pp. 386-391.

${ }^{81}$ Article 3(1) lit. e TFEU.

${ }^{82}$ Article 2(1) TFEU.
} 
the new generation of trade agreements with highly developed regulatory aspects. ${ }^{83}$ In the CJEU's judgment in Daiichi Sankyo, it ruled that the CCP, as amended by the Lisbon Treaty, and in contrast to the pre-Lisbon case law, extends over the entire area substantively covered by the WTO's Agreement on Trade-Related Aspects of Intellectual Property Rights (TRIPS). ${ }^{84}$ Furthermore, in the context of trade in services, the Court found in its judgment on the conclusion of the European Convention on the legal protection of services based on, or consisting of, conditional access that the proper legal basis for this is the CCP as defined in Article 207 TFEU, ${ }^{85}$ and that therefore the Convention cannot become a mixed agreement. The underlying logic for this finding was concisely explained by Advocate General Kokott in her opinion:

Article 207 TFEU can serve a fortiori as the legal basis for measures which do not lead to harmonisation of legislative provisions of the Member States within the Union (internal harmonisation) but, as in this case, contribute, in respect of external relations, to the approximation of the legislative provisions in the Union and in third countries (external harmonisation). The object of many modern trade agreements is precisely this kind of harmonisation: those agreements provide for the creation of uniform legal standards - if appropriate in the form of minimum standards - for certain products, activities or sectors with a view to facilitating cross-border trade. ${ }^{86}$

Hence, the Court has taken up again its approach to the CCP from before opinion $1 / 94$ in terms of the congruence of the scope of WTO obligations and the extent of EU competence in the $\mathrm{CCP},{ }^{87}$ but within a significantly enhanced framework, adapted to the realities of twenty-first century international trade policy.

\subsection{The Diminished Relevance of the Duty of Sincere Cooperation}

The preceding observations have an important consequence for the duty of sincere cooperation as a legal principle in the CCP. Infringing upon the EU's exclusive competence by a Member State represents in itself a violation of the Treaties, which

\footnotetext{
${ }^{83}$ See Ankersmit (2014). Also in the area of foreign direct investment, interesting legal development can be expected, though rather as part of a long-term process, see Dimopoulos (2012). After opinion $2 / 15$, however, it is clear that non-direct investments and investor-state dispute settlement remain firmly within the domain of shared competences, CJEU, opinion 2/15, EU-Singapore FTA, ECLI:EU:C:2017:376.

${ }^{84}$ CJEU, case C-414/11, Daiichi Sankyo and Sanofi-Aventis Deutschland, ECLI:EU:C:2013:520.

${ }^{85} \mathrm{CJEU}$, case C-137/12, Commission v. Council (Conditional Access Convention), ECLI:EU: C:2013:675.

${ }^{86}$ Opinion of Advocate General Kokott to CJEU, case C-137/12, Commission v. Council (Conditional Access Convention), ECLI:EU:C:2013:441, para. 67.

${ }^{87}$ See Hahn and Danieli (2013), p. 49 et seq.
} 
does not require an additional finding on disloyal behaviour. ${ }^{88}$ It is still possible that the CJEU may address and admonish, in addition, violations of the duty of sincere cooperation by the Member States, such as providing information in an inadequate and untimely fashion to the Union institutions. ${ }^{89}$ However, it is highly unlikely, in view of the case law to date, that the CJEU would find a violation in the area of the CCP solely on the basis on the duty of sincere cooperation according to Article 4(3) TEU. ${ }^{90}$ It would in fact be a masterly feat in illegal behaviour if a Member State succeeded, given the current state of the primary law and CJEU case law, to manage to violate its duty of sincere cooperation within the $\mathrm{CCP}$ while, at the same time, fully respecting both the exclusive competence of the EU in this area and other specific EU law obligations.

Moreover, what distinguishes the CCP from the settings in opinion 2/91 and the $I M O$ and $O I V$ cases, is that the EU is represented prominently both within the WTO and at the negotiating table for trade agreements by the Commission. Hence, in both these cases the objectives and interests of the Union can be pursued without the assistance of Member States acting as "trustees". The EU is a founding member and fully-fledged party of the WTO. ${ }^{91}$ It can look back on decades of active practice in the General Agreement on Tariffs and Trade (GATT) prior to the establishment of the WTO. ${ }^{92}$

Not least in WTO dispute settlement procedures, including when it comes to the use of retaliatory measures, regarding which the CJEU had emphasized the importance of loyal cooperation in opinion $1 / 94$, one can observe that in practice it is

\footnotetext{
${ }^{88}$ By way of analogy, see CJEU, case C-114/12, Commission v. Council (Convention on the Rights of Broadcasting Organizations), ECLI:EU:C:2014:2151, para. 103, where the CJEU found that the adoption of a "hybrid act" (para. 34) by the Council and the Member States to conclude the international agreement in question violated the exclusive competence of the Union according to Article 3(2) TFEU, resulting in the annulment of the decision. Following this finding, the Court refrained from going into the other pleas brought forward by the Commission, one of which claimed a violation of inter-institutional cooperation duties based on Article 13(2) TEU (para. 104). See also CJEU, case C-459/03, Commission v. Ireland (Mox Plant), ECLI:EU: C:2006:345, para. 171, where the CJEU refrained from ruling on an alleged "failure to comply with the general obligations contained in Article $10 \mathrm{EC}$ [now Article 4(3) TEU] that is distinct from the failure, already established, to comply with the more specific Community obligations devolving on Ireland pursuant to Article 292 EC [now Article 344 TFEU]" on the exclusive jurisdiction of the CJEU.

${ }^{89}$ It should be noted here that also in CJEU, case C-45/07, Commission v Greece (IMO), ECLI:EU: C:2009:81, para. 26, the CJEU did not only find a violation of the duty of loyal cooperation by the Member States in question, but a "breach of that State's obligations, which, in a case such as the present, arise under Articles $10 \mathrm{EC}, 71 \mathrm{EC}$ and 80(2) [TEC]", which were "likely to affect Community rules promulgated for the attainment of the objectives of the Treaty".

${ }^{90}$ This occurred, by contrast, in the context of shared competences, see CJEU, case C-246/07, Commission v. Sweden (PFOS), ECLI:EU:C:2010:203, where the CJEU found a violation the duty of loyal cooperation in Article 10 TEC (now Article 4(3) TEU), but did not detect any other breach of EU law obligations.

${ }^{91}$ Article XI:1 Agreement Establishing the World Trade Organization.

${ }^{92} \mathrm{CJEU}$, joined cases 21 to 24/72, International Fruit, ECLI:EU:C:1972:115, para. 18.
} 
always the EU, represented by the Commission, which launches complaints and never the Member States. Moreover, the Commission takes on the defence whenever a third country starts a complaint against an EU Member State, even when it comes to issues that could not be clearly classified as belonging within the realm of exclusive Union competences at the time. ${ }^{93}$ One can therefore assume that the Member States have by now been "socialized" or "Europeanized" extent that loyal (and therefore rather restrained) behaviour in the WTO has already become a common practice that requires little to no judicial intervention with reference to Article 4(3) TEU anymore.

Firstly, treaty reform and recent case law, and, secondly, decades of practice, hence point in the same direction with regard to the future relevance of the duty of sincere cooperation in the CCP: The less "mixed" the distribution of powers between Union and Member States in the WTO or in the negotiation of trade agreements, and the stronger the Union's external representation through the Commission, the less need there is legally and practically to make use of sincere cooperation as a justiciable legal obligation.

\section{Outlook: The EU's Global Strategy, "Brexit", the WTO, and New Free Trade Agreements}

Looking to the future, several relevant developments arise regarding the direction of the CCP and the relevance of sincere cooperation as a legal principle: firstly, the EU's new core foreign policy document, the Global Strategy on Foreign and Security Policy and its implementation; secondly, the UK's referendum on EU membership and the prospects of a "hard Brexit"; thirdly, the future representation of the Member States in the WTO; and fourthly, the current wave of new trade agreements that the EU is negotiating with third parties.

\subsection{The Common Commercial Policy and the Global Strategy for Foreign and Security Policy}

Since June 2016, the EU has a new, overarching policy document for its external action. The Global Strategy for Foreign and Security Policy, entitled "Shared

\footnotetext{
${ }^{93}$ See as examples for situations in which, despite a complaint launched against a Member State alone, it was the Union that acted as the party to the mutually agreed solution: Notification of Mutually Agreed Solution, Belgium-Administration of Measures Establishing Customs Duties for Rice, WT/DS210/6, 2 January 2002; and Notification of Mutually Agreed Solution, IrelandMeasures Affecting the Grant of Copyright, WT/DS82/3 and European Communities-Measures Affecting the Grant of Copyright and Neighbouring Rights, WT/DS115/3, 13 September 2002. See in detail Delgado Casteleiro and Larik (2013).

${ }^{94}$ See on this concept from political science in the context of EU external relations, Wong (2011).
} 
Vision, Common Action: A Stronger Europe", 95 was presented to the European Council by High Representative Federica Mogherini. ${ }^{96}$ The European Council noted in its subsequent Conclusions that it "welcomes the presentation of the Global Strategy for the European Union's Foreign and Security Policy by the High Representative and invites the High Representative, the Commission and the Council to take the work forward." 97 Unlike the 2003 European Security Strategy, or the Global Europe trade strategy for that matter, the Global Strategy is not policy-specific, but covers all areas of EU external relations, including trade. Consequently, even though not a legally binding act, the document is relevant for the embedding of the CCP within the overall direction of EU foreign policy and for the relationship between the Union and the Member States on the international stage.

In terms of substance, the Global Strategy stresses the concepts of "resilience" and a "joined-up approach" in terms of both policies and actors. Concerning the $\mathrm{CCP}$, the Strategy refers to trade policy under the heading "Resilience in our Surrounding Regions":

Echoing the Sustainable Development Goals, the EU will adopt a joined-up approach to its humanitarian, development, migration, trade, investment, infrastructure, education, health and research policies, as well as improve horizontal coherence between the EU and its Member States. ${ }^{98}$

The linkages between trade and other areas of external action are also highlighted elsewhere. For instance, the Strategy stresses that "trade and development - working in synergy - can underpin long-term peacebuilding". 99

Trade agreements are mentioned in this context as instruments for a wider foreign policy agenda "to underpin sustainable development, human rights protection and rules-based governance." 100 This same idea is also expressed when the Strategy turns to "Cooperative Regional Orders". It mentions the series of Economic Partnership Agreements (EPAs) as a means to "spur African integration and mobility, and encourage Africa's full and equitable participation in global value chains". ${ }^{101}$ Moreover, it portrays the Transatlantic Trade and Investment Partnership (TTIP) with the United States and the Comprehensive Economic and Trade

\footnotetext{
${ }^{95}$ Shared Vision, Common Action: A Stronger Europe, A Global Strategy for the European Union's Foreign and Security Policy, June 2016.

${ }^{96}$ For the background and process leading to the Global Strategy, see Tocci (2016).

${ }^{97}$ European Council, Conclusions, EUCO 26/16, Brussels, 28 June 2016, para. 20.

${ }^{98}$ Shared Vision, Common Action: A Stronger Europe, A Global Strategy for the European Union's Foreign and Security Policy, June 2016, p. 26.

${ }^{99}$ Shared Vision, Common Action: A Stronger Europe, A Global Strategy for the European Union's Foreign and Security Policy, June 2016, p. 31. See also p. 36, where it is noted that the EU "will build stronger links between our trade, development and security policies in Africa".

${ }^{100}$ Shared Vision, Common Action: A Stronger Europe, A Global Strategy for the European Union's Foreign and Security Policy, June 2016, pp. 26-27.

${ }^{101}$ Shared Vision, Common Action: A Stronger Europe, A Global Strategy for the European Union's Foreign and Security Policy, June 2016, p. 36.
} 
Agreement (CETA) with Canada as means to strengthen "the transatlantic commitment to shared values and signals our willingness to pursue an ambitious rulesbased trade agenda." ${ }^{102}$ Lastly, trade features prominently in the section on "Global Governance in the 21st Century". There, the Strategy notes that "[a]mbitious agreements built on mutual benefits [...] can promote international regulatory standards, consumer protection, as well as labour, environmental, health and safety norms," serving "as building blocks of global free trade". 103

Bringing this back to the law, and sincere cooperation as a legal principle in particular, the Global Strategy can be understood as an important step towards the translation into policy of the embedding of the CCP into EU external action in the post-Lisbon TEU. On the one hand, this speaks to the "hinge" included in Article 207 TFEU stating that the CCP "shall be conducted in the context of the principles and objectives of the Union's external action". ${ }^{104}$ This entails a positive obligation on both the EU institutions and the Member States to pursue their foreign policies based on the objectives in the Treaties and as fleshed out further in the Global Strategy. On the other hand, as a policy document, the Strategy is of course not capable of changing in any way the division of competences between EU and Member States. The Strategy itself stresses that the EU's "diplomatic action must be fully grounded in the Lisbon Treaty". ${ }^{105}$ Hence, when the Global Strategy states that "EU foreign policy is not a solo performance: it is an orchestra which plays from the same score", ${ }^{106}$ this applies in the first place to areas which do not fall within the Union's exclusive competence. Given the extended scope of EU trade policy as an exclusive competence outlined above, the CCP is in fact very much a "solo performance" of the EU on the international stage, with the Member States not disappearing altogether, but rather acting as "backing vocals".

What the Global Strategy serves as a reminder of, in sum, is the need for sincere cooperation and coherence between different policies, which is especially relevant in areas of shared competence or when the EU and the Member States endeavor to implement a holistic approach vis-à-vis strategic partners. Such approaches will in most cases have a trade dimension, but also others, including security, development, human rights, and environmental aspects. Judicially, the duty of sincere cooperation will play continue to play a role in these cases-not least since it is of general application across all Union policies. However, the more trade-focused

\footnotetext{
${ }^{102}$ Shared Vision, Common Action: A Stronger Europe, A Global Strategy for the European Union's Foreign and Security Policy, June 2016, p. 37. See also p. 38, where the Strategy notes the ambition to work "towards ambitious free trade agreements with strategic partners such as Japan and India, as well as ASEAN member states".

${ }^{103}$ Shared Vision, Common Action: A Stronger Europe, A Global Strategy for the European Union's Foreign and Security Policy, June 2016, p. 41.

${ }^{104}$ Article 207(1) TFEU.

${ }^{105}$ Shared Vision, Common Action: A Stronger Europe, A Global Strategy for the European Union's Foreign and Security Policy, June 2016, p. 46.

${ }^{106}$ Shared Vision, Common Action: A Stronger Europe, A Global Strategy for the European Union's Foreign and Security Policy, June 2016, p. 46.
} 
and "less mixed" a particular approach or agreement, the less need there will be to rely on loyalty due to the EU's exclusive competence.

\section{2 "Brexit" and Sincere Cooperation of the EU27}

As the Global Strategy acknowledges, the EU finds itself in a time of "existential crisis". ${ }^{107}$ This is in the first place a reference to the referendum on EU membership in the UK, which was held on 23 June 2016 - only a few days before the Global Strategy was launched-and resulted in a majority for leaving the European Union. In the turmoil that followed and is still ongoing, it is hard to say when and how the UK will leave. However, with the new British government being ostensibly committed to go through with the withdrawal, ${ }^{108}$ "Brexit" seems increasingly a question of "when" rather than "if". This will lead to a myriad of legal intricacies, which will certainly not fail to garner scholarly attention. As far as the Common Commercial Policy and the duty of sincere cooperation are concerned, a number of legal observations can be made already now. These concern, on the one hand, the United Kingdom, and, on the other, the remaining 27 EU Member States, now referred to as the "EU27". ${ }^{109}$ Overall, these confirm the findings above that the duty of sincere cooperation remains relevant, but is to a large extent overshadowed by the presence of a broadly defined exclusive Union competence in the area of trade.

As far as the UK is concerned, it did not cease to be a member when it triggered Article 50 TEU on 29 March 2017, ${ }^{110}$ but will remain a member at least until "the date of entry into force of the withdrawal agreement or, failing that, two years" after triggering Article 50 TEU. ${ }^{111}$ Time to negotiate the exit deal could even be

\footnotetext{
${ }^{107}$ Shared Vision, Common Action: A Stronger Europe, A Global Strategy for the European Union's Foreign and Security Policy, June 2016, p. 13.

${ }^{108}$ Prime Minister Theresa May seemed to even suggest a "hard Brexit", stating in her speech to the Conservative Party conference in October 2015: "I want it to give British companies the maximum freedom to trade with and operate within the Single Market - and let European businesses do the same here. But let's state one thing loud and clear: we are not leaving the European Union only to give up control of immigration all over again. And we are not leaving only to return to the jurisdiction of the European Court of Justice. That's not going to happen." As reproduced in: Theresa May's keynote speech at Tory conference in full, The Independent, 5 October 2016. See also Prime Minister's Office, The government's negotiating objectives for exiting the EU: PM speech, London, 17 January 2017, https://www.gov.uk/government/speeches/the-governmentsnegotiating-objectives-for-exiting-the-eu-pm-speech (last accessed 1 March 2017).

${ }^{109}$ See, e.g., Zalan, EU 27 meet for 'moment of truth', EUobserver, 16 September 2016, https:// euobserver.com/political/135123 (last accessed 1 March 2017).

${ }^{110}$ More precisely Article 50(2) TEU.

${ }^{111}$ Article 50(3) TEU.
} 
extended if all parties agree. ${ }^{112}$ During that period, the UK remains bound by EU law, including the duty to respect the exclusive competence of the EU in trade policy as well as the duty of sincere cooperation in general. Under areas of exclusive competence, Member States can only act "if so empowered by the Union or for the implementation of Union acts." ${ }^{.113}$ For instance, authorizing the UK to start trade negotiations with third countries would be a possibility, especially for the period after triggering Article 50 TEU, but depends entirely on the goodwill of the EU institutions and the remaining Member States.

Apart from that, the obligations of still being an EU member stand in clear tension with any plans to start negotiations on trade agreements with third countries during this period. The latter would be a (basic) textbook example of a violation of the EU's exclusive competence under Article 3(2) TFEU. Thus far, the UK government brands its talks with non-EU partners on trade agreements as "preliminary discussions" 114 rather than negotiations-also arguably because there is little in terms of substance to negotiate about as long as the future relationship with the EU and its internal market is not clarified. However, looking at the existing body of CJEU case law, even such exploratory talks could be regarded as infringing upon the exercise of the EU's competence in combination with a violation of the duty of sincere cooperation incumbent on the UK vis-à-vis the EU institutions and the EU27.

As the CJEU pointed out in the PFOS judgment, which even concerned shared competences, if a Member State acts internationally in such a way that is "likely to compromise the principle of unity in the international representation of the Union and its Member States and weaken their negotiating power", ${ }^{115}$ a violation of the duty of sincere cooperation can be detected. As the Court found in the earlier Inland Waterways cases, the Member States are barred from negotiating with third countries on matters which are covered already in ongoing negotiations by the EU. ${ }^{116}$ This would be the situation as soon as "preliminary discussions" by the UK with countries such as the United States, Canada and others with which the EU is in the process of negotiating or concluding FTAs reach a minimum threshold of specificity and could be detrimental to the EU's own position in these negotiations. It would be up for the CJEU to determine this threshold, though the Commission might opt to refrain from bringing infringement proceedings against the UK for political reasons. Depending on how "hard" "Brexit" and the negotiations leading up to it

\footnotetext{
${ }^{112}$ Article 50(3) TEU. However, the period after triggering Article 50 TEU and before leaving would be legally even more "complex", Cremona, Negotiating Trade Deals Before Brexit?, Social Europe, 25 July 2016, https://www.socialeurope.eu/2016/07/negotiating-trade-deals-brexit/ (last accessed 1 March 2017).

${ }^{113}$ Article 2(1) TFEU.

${ }^{114}$ Theresa May: UK will lead world in free trade, BBC News, 7 September 2016, http://www.bbc. com/news/uk-politics-37291832 (last accessed 1 March 2017).

${ }^{115}$ CJEU, case C-246/07, Commission v. Sweden (PFOS), ECLI:EU:C:2010:203, para. 104.

${ }^{116} \mathrm{CJEU}$, case C-433/03, Commission v. Germany (Inland Waterways), ECLI:EU:C:2005:462; and CJEU, case C-266/03, Commission v. Luxembourg (Inland Waterways), ECLI:EU: C:2005:341.
} 
may become, the latter remains an option for the Commission and the remaining 27 Member States. ${ }^{117}$

Once "Brexit" would be complete, however, the "Treaties shall cease to apply" $" 18$ to the UK, including its obligation to cooperate in the spirit of loyalty with the EU. Time will tell, to use the words of Boris Johnson, now the UK's Foreign Secretary, uttered shortly after the referendum, how Britain will fare in the world of international trade once it can "stand tall" and act "without being elbowed aside by a supranational body." 119 As a legal matter, it should be noted that also the EU institutions and the EU27 would have no obligations of loyalty against the UK anymore. Rather than "elbowing aside" the UK, the European Commission could simply sue the UK at the WTO and even impose trade sanctions, either under WTO dispute settlement or a possible future EU-UK trade agreement.

As regards the EU27 Member States, they would of course remain bound by their duty of sincere cooperation towards the EU, before, during and after "Brexit" negotiations. Internationally, they will continue to have to defend the common interest, uphold common positions and refrain from actions that could undermine the EU's negotiating position. Concerning the interaction with the departing UK, the exclusive competence of the EU in trade matters prohibits them from engaging in any separate negotiations with Britain. Hence, earlier suggestions by the UK's "Brexit" secretary David Davis "that Britain would negotiate individual trade deals with other EU countries" 120 are therefore manifestly at odds with the obligations of the EU27 under EU law both in terms of respecting the EU's competences and the duty of sincere cooperation. Here, it can be expected that the European Commission would not hesitate to bring infringement proceedings in the case of a Member State stepping out of line, given that this would question the cohesion of the Union as a whole. If any of the EU27 wanted to do that, they would have to first leave the EU themselves. This serves as another example of the overall argument of the article. The violation of the EU's exclusive competence would be both obvious and sufficient to declare such behaviour illegal. Sincere cooperation would only serve to confirm further what is already apparent.

\footnotetext{
${ }^{117}$ Article 258 and Article 259 TFEU, respectively.

${ }^{118}$ Article 50(3) TEU.

${ }^{119}$ See the transcript of his remarks in Boris Johnson: I will not be the next Tory leader, The Spectator, 30 June 2016, http://blogs.spectator.co.uk/2016/06/boris-johnson-will-not-next-toryleader/ (last accessed 1 March 2017).

${ }^{120}$ Stone, Minister for Brexit David Davis appeared unaware of how EU trade deals actually work, The Independent, 14 July 2016, http://www.independent.co.uk/news/uk/politics/minister-forbrexit-davis-davis-eu-european-union-germany-single-market-trade-deals-unaware-mistakea7136121.html (last accessed 1 March 2017).
} 


\subsection{Continued WTO Membership of the Member States}

Regarding the future representation of the Member States in the WTO (possibly minus the UK), a simple truth prevails. The new division of competences, confirmed by the recent CJEU case law (see Sect. 4.1 above), does not herald the end of the membership of the Member States in the WTO. ${ }^{121}$ This again underlines the future-albeit somewhat qualified-importance of the principle of sincere cooperation in the CCP.

The German Federal Constitutional Court noted already in its Lisbon judgment of 2009 that the "Treaty of Lisbon may at any rate not force the Member States to waive their [WTO] member status". ${ }^{122}$ The Court also rejected the "idea that the Member States' own legal personality status in external relations gradually takes second place to a European Union which acts more and more clearly in analogy to a state" and stressed that the "development to date of a membership that is cooperatively mixed and is exercised in parallel" can be "a model for other international organisations and other associations of states". ${ }^{123}$ However, the Court cautioned, "in so far as the development of the European Union in analogy to a state were to be continued on the basis of the Treaty of Lisbon, which is open to development in this context, this would come into conflict with constitutional foundations."124

Hence, also eight years after the entry into force of the Lisbon Treaty, including its explicit provision in the primary law on protecting the national identity of the Member States in Article 4(2) TEU, one has to conclude that sincere cooperation and the pursuit of common goals in the area of foreign policy and global governance cannot serve to deny the international legal personality and international actorness of the Member States. Union loyalty, including in the area of the CCP, is not to be understood as equating sole representation of the EU and all the Member States on the international stage. The substantive scope of the WTO, which is not set in stone despite the deadlocked Doha Round, remains from the legal point of view of the EU "mixed"-but "less mixed" due to the Lisbon reforms and in view of the recent case law confirming a much larger proportion now clearly falling within the exclusive competence of the Union. For Member States, this means that they will have to exercise their — at times rather nominal than substantial-international legal personality with even more self-restraint. It remains a matter of politics whether the parallel representation of Union and Member States at the WTO will continue to be seen as desirable against this background. Legally, the continued existence of the 28 (or 27 in the future) mostly taciturn Member State delegations at the WTO is not

\footnotetext{
${ }^{121}$ See also already Tietje (2006), p. 171 et seq.

${ }^{122}$ Judgment of the German Federal Constitutional Court (Second Senate) of 30 June 2009, 2 BvE 2/08, para. 375 .

${ }^{123}$ Judgment of the German Federal Constitutional Court (Second Senate) of 30 June 2009, 2 BvE 2/08, para. 376 .

${ }^{124}$ Judgment of the German Federal Constitutional Court (Second Senate) of 30 June 2009, 2 BvE 2/08, para. 376 .
} 
to be seen as an act of disloyalty in itself-rather perhaps as a matter of expense for the European taxpayer.

\subsection{Mixity and Cooperation in the New Free Trade Agreements}

A similar picture as with WTO membership emerges with regard to the new generation of deep and comprehensive free trade agreements. For instance, the "mixed" nature of CETA and TTIP remains disputed. More legal clarity was provided by the CJEU's opinion on the EU-Singapore FTA, ${ }^{125}$ but this does not rule out that agreements might still be concluded as "mixed" for political reasons only, ${ }^{126}$ even if the content is adapted to be exclusive from a legal point of view. Given the fact that there are still grey areas and that by inserting provisions on political dialogue agreements can be intentionally made "mixed", 127 it is unlikely that the Member States will abandon the practice of "mixed" trade agreements, including through insisting on it through litigation at the CJEU.

What is certain is that Article 4(3) TEU and other specific manifestations of sincere cooperation in the Treaties will require, as a judicially enforceable duty, from the Member States cooperative and loyal behaviour. This will apply regardless of the fact whether EU trade agreements with third countries-or other regional organizations such as ASEAN-will in the future be concluded with or without the Member States as parties. In situations where the Member States would not become parties, the agreements in their entirety will have to be regarded as part of EU law according to Article 216(2) TFEU and will have to be fully implemented by the EU and the Member States. By contrast, in situations where these agreements remain "mixed", the general duty of sincere cooperation assumes a more prominent role as it obliges the Member States to implement those parts of these agreements that fall within their own competence. ${ }^{128}$ As regards the external actions of the Member States, ranging from the negotiation of trade agreements to acts in bodies created by

\footnotetext{
${ }^{125}$ CJEU, opinion 2/15, EU-Singapore FTA, ECLI:EU:C:2017:376.

${ }^{126}$ See European Commission, Press Release: European Commission proposes signature and conclusion of EU-Canada trade deal, IP-16-2371, Strasbourg, 5 July 2016, which includes the following quote from EU Trade Commissioner Cecilia Malmström: "Meanwhile, the open issue of competence for such trade agreements will be for the European Court of Justice to clarify, in the near future. From a strict legal standpoint, the Commission considers this agreement to fall under exclusive EU competence. However, the political situation in the Council is clear, and we understand the need for proposing it as a 'mixed' agreement, in order to allow for a speedy signature." After the delay caused by the region of Wallonia, however, the Commission may revisit the idea that mixity contributes to a more "speedy" process.

${ }^{127}$ Gstöhl and Hanf (2014), p. 739; Streinz (2015).

${ }^{128} \mathrm{CJEU}$, case C-13/00, Commission v. Ireland (Berne Convention), ECLI:EU:C:2002:184; CJEU, case C-239/03, Commission v. France (Étang de Berre), ECLI:EU:C:2004:598.
} 
those agreements, the same applies as was mentioned above in the WTO context. In the now significantly expanded areas of exclusive Union competence, utmost restraint is required from the Member States. But even in areas of shared competence, the duty of sincere cooperation cautions the Member States against rash autonomous actions and obliges them to regularly consult and share information with the EU institutions.

Lastly, it should be noted that, on the one hand, the Union has to respect the identity, including the international legal personality, of the Member States according to Article 4(2) TEU. On the other hand, this does not amount to a requirement to facilitate and preserve "polyphony" in the external action of the Union and the Member States. If the latter decide to terminate a specific trade agreement or withdraw from an international organization, given the EU's extensive competences, expertise and ability to solely represent the common interest, ${ }^{129}$ then the principle of sincere cooperation would require that the EU respect such a decision by the Member States concerned, rather than prompt them to maintain the "polyphony" in the EU's external representation.

\section{Conclusion}

The article availed itself of the opportunity to look back on more than half a decade of law and practice after the entry into force of the Lisbon Treaty as regards the $\mathrm{CCP}$, in particular the relationship between the EU and its Member States. The contours of the consequences of the Lisbon reform of the primary law are now becoming more clearly visible. This also sets the stage for the conduct of the external action of the Union in the mid to long-term. The Common Commercial Policy, which has a relatively long history and is closely linked to the economic weight of the internal market, is now more than ever embedded in the overall foreign policy of the EU and its ambitions for shaping global governance. This finds its latest and most high-profile confirmation in the EU's Global Strategy for Foreign and Security Policy.

Implementing these ambitions is a constitutional mandate of the EU institutions and Member States alike, which all have to contribute and work together in the spirit of loyalty. Against this background, the preceding reflections on the importance of the duty of sincere cooperation in the CCP can be summarized in three main points. Firstly, the duty of sincere cooperation remains an important structural principle of constitutional rank for the external action of the Union, especially in the

\footnotetext{
${ }^{129}$ An example for such a development is the membership of the European Convention on the Legal Protection of Services based on, or consisting of, Conditional Access. Several Member States have withdrawn from this agreement after the EU became a party and following the CJEU ruling that the EU had exclusive competence in the area covered by the agreement, see CJEU, case C-137/12, Commission v. Council (Conditional Access Convention), ECLI:EU:C:2013:675. See Larik (2015b), p. 795.
} 
context of "polyphony" of the Member States and Union institutions at the international level. It also applies fully to Member States which may decide to withdraw from the Union until the moment they cease to be members. To paraphrase British Prime Minister May: Sincere cooperation means sincere cooperation. And the CJEU will enforce it. Secondly, the case law of the CJEU reveals the wide scope of application of the duty, also and especially in the area of shared external powers, which can at times take the form of a "duty to remain silent" Member States in the international arena. Thirdly, in the specific context of the $\mathrm{CCP}$, the duty of sincere cooperation will play a less significant role as a legal principle in the future. This shift is due, on the one hand, to the fact that the Lisbon Treaty, confirmed by the subsequent case law of the CJEU, extended the scope of the CCP significantly and confirmed its nature as an exclusive Union competence. On the other hand, its diminished legal relevance is due to the EU's strong presence at the WTO and in the negotiation of free trade agreements. This does not entail the abandonment of the missions of the Member States to the WTO or the end of mixed trade agreements in the future. Rather, this shift signifies a tangible contribution towards coherent and targeted cooperation in the day-to-day exercise of EU trade policy as part of its global outreach-in short, a contribution to more harmony in a changing soundscape in Europe and the world.

\section{References}

Ankersmit L (2014) The scope of the common commercial policy after Lisbon: the Daiichi Sankyo and conditional access services grand chamber judgments. Leg Issues Econ Integr 41 (2):193-209

Cremona M (2009) Extending the reach of the AETR principle: comment on Commission v Greece (C-45/07). Eur Law Rev 34(5):754-768

Cremona M (2011) Member States as Trustees of the union interest: participating in international agreements on behalf of the European Union. In: Arnull A, Bernard C, Dougan M, Spaventa E (eds) A constitutional order of states: essays in European Law in honour of Alan Dashwood. Hart Publishing, Oxford, pp 435-457

Dashwood A (2014) The continuing bipolarity of EU external action. In: Govaere I, Lannon E, Van Elsuwege P, Adam S (eds) The European Union in the world: essays in honour of Marc Maresceau. Martinus Nijhoff, Leiden, pp 3-16

De Baere G (2011) O, Where is Faith? O, Where is Loyalty? Some thoughts on the duty of loyal co-operation and the union's external environmental competences in the light of the PFOS case. Eur Law Rev 36(3):405-419

De Baere G, Roes T (2015) EU loyalty as good faith. Int Compar Law Q 64(4):829-874

Dederer HG (2013) The common commercial policy under the influence of commission, council, high representative and European external action service. In: Bungenberg M, Hermann C (eds) European yearbook of international economic law. Special issue: Common commercial policy after Lisbon. Springer, Heidelberg, pp 87-105

Delgado Casteleiro A, Larik J (2011) The duty to remain silent: limitless loyalty in EU external relations? Eur Law Rev 36(4):522-539

${ }^{130}$ Delgado Casteleiro and Larik (2011). 
Delgado Casteleiro A, Larik J (2013) The "odd couple": the responsibility of the EU at the WTO. In: Evans M, Koutrakos P (eds) The international responsibility of the European Union. Hart Publishing, Oxford, pp 233-255

Dimopoulos A (2010) The effects of the Lisbon Treaty on the principles and objectives of the common commercial policy. Eur Foreign Aff Rev 15(2):153-170

Dimopoulos A (2012) The compatibility of future EU investment agreements with EU law. Leg Issues Econ Integr 39(4):447-471

Engbrink SD (2014) Die Kohärenz des auswärtigen Handelns der Europäischen Union. Mohr Siebeck, Tübingen

Epping V (2014) Völkerrechtssubjekte. In: Ipsen K (ed) Völkerrecht, 6th edn. C.H. Beck, Munich, pp 46-386

Govaere I (2014) Novel issues pertaining to EU Member States membership of other international organizations: the OIV case. In: Govaere I, Lannon E, Van Elsuwege P, Adam S (eds) The European Union in the world: essays in honour of Marc Maresceau. Martinus Nijhoff, Leiden, pp 225-243

Govaere I, Capiau J, Vermeersch A (2004) In-between seats: the participation of the European Union in international organizations. Eur Foreign Aff Rev 9(2):155-187

Gstöhl S, Hanf D (2014) The EU's post-Lisbon free trade agreements: commercial interests in a changing constitutional context. Eur Law J 20(6):733-748

Hahn M, Danieli L (2013) You'll never walk alone: the European Union and its member states in the WTO. In: Bungenberg M, Hermann C (eds) European yearbook of international economic law. Special issue: Common commercial policy after Lisbon. Springer, Heidelberg, pp 49-63

Hatje A (2001) Loyalität als Rechtsprinzip der Europäischen Union. Nomos, Baden-Baden

Heliskoski J (2001) Mixed agreements as a technique for organizing the international relations of the European Community and its member states. Kluwer, The Hague

Herrmann C (2002) Common commercial policy after nice: Sisyphus would have done a better job. Common Mark Law Rev 39(1):7-29

Hillion C (2010) Mixity and coherence in EU external relations: the significance of the "duty of cooperation". In: Hillion C, Koutrakos P (eds) Mixed agreements revisited: the EU and its member states in the world. Hart Publishing, Oxford, pp 87-115

Hillion C (2014) A powerless court? The European Court of Justice and the common foreign and security policy. In: Cremona C, Thies A (eds) The European Court of Justice and external relations law: constitutional challenges. Hart Publishing, Oxford, pp 47-70

Hoffmeister F (2013) Aktuelle Rechtsfragen in der Praxis der europäischen Außenhandelspolitik. Zeitschrift für Europarechtliche Studien 16(4):385-401

Hoffmeister F, Kuijper PJ (2006) The status of the European Union at the United Nations: institutional ambiguities and political realities. In: Wouters J, Hoffmeister F, Ruys T (eds) The United Nations and the European Union: an ever stronger partnership. T.M.C. Asser Press, The Hague, pp 9-34

Hyett I (2000) The duty of cooperation: a flexible concept. In: Dashwood A, Hillion C (eds) The general law of EC external relations. Sweet \& Maxwell, London, pp 248-253

Kaiser F (2009) Gemischte Abkommen im Lichte bundesstaatlicher Erfahrungen. Mohr Siebeck, Tübingen

Klamert M (2014) The principle of loyalty in EU Law. Oxford University Press, Oxford

Koutrakos P (2015) EU international relations law, 2nd edn. Hart Publishing, Oxford

Larik J (2011) Much more than trade: the common commercial policy in a global context. In: Evans M, Koutrakos P (eds) Beyond the established legal orders: policy interconnections between the EU and the rest of the world. Hart Publishing, Oxford, pp 13-46

Larik J (2015a) Good global governance through trade: constitutional moorings. In: Wouters J, Marx A, Geraets D, Natens B (eds) Global governance through trade: EU policies and approaches. Edward Elgar, Cheltenham, pp 43-70

Larik J (2015b) No mixed feelings: the post-Lisbon common commercial policy in Daiichi Sankyo and Commission v. Council (conditional access convention). Common Mark Law Rev 52(3):779-799 
Larik J (2016) Foreign policy objectives in European constitutional law. Oxford University Press, Oxford

McCormick J (2008) Understanding the European Union: a concise introduction, 4th edn. Palgrave Macmillan, Basingstoke

Meunier S, Nicolaïdis K (2011) The European Union as a trade power. In: Hill C, Smith M (eds) International relations and the European Union, 2nd edn. Oxford University Press, Oxford, pp 275-298

Millet FX (2013) L’Union européenne et l'identité constitutionnelle des États membres. L.G.D.J, Paris

Neframi E (2010) The duty of loyalty: rethinking its scope through its application in the field of EU external relations. Common Mark Law Rev 47(2):323-359

Piris JC (2010) The Lisbon Treaty: a legal and political analysis. Cambridge University Press, Cambridge

Streinz R (2015) Disputes on TTIP: does the agreement need the consent of the German Parliament? In: Herrmann C, Simma B, Streinz R (eds) European yearbook of international economic law. Special issue: Trade policy between law, diplomacy and scholarship. Springer, Heidelberg, pp 271-295

Thies A (2012) The PFOS decision of the ECJ: the member states' obligation to refrain from unilateral external action in areas of shared competence. In: Díez-Hochleitner J, Martinez Capdevila C, Blazquez Navarro I, Frutos Miranda J (eds) Recent trends in the case law of the Court of Justice of the European Union (2008-2011). La Ley, Madrid, pp 703-728

Tietje C (2006) Das Ende der parallelen Mitgliedschaft von EU und Mitgliedstaaten in der WTO? In: Herrmann C, Krenzler G, Streinz R (eds) Die Außenwirtschaftspolitik der Europäischen Union nach dem Verfassungsvertrag. Nomos, Baden-Baden, pp 161-173

Tocci N (2016) The making of the EU global strategy. Contemp Secur Policy 37(3):461-472

Vedder C (2013) Linkage of the common commercial policy to the general objectives for the union's external action. In: Bungenberg M, Hermann C (eds) European yearbook of international economic law. Special issue: Common commercial policy after Lisbon. Springer, Heidelberg, pp 115-144

Wong R (2011) The Europeanization of foreign policy. In: Hill C, Smith M (eds) International relations and the European Union, 2nd edn. Oxford University Press, Oxford, pp 149-171

Wouters J, Odermatt J, Ramopoulos T (2016) The EU in the world of international organizations: diplomatic aspirations, legal hurdles and political realities. In: Smith M, Keukeleire S, Vanhoonacker S (eds) The diplomatic system of the European Union: evolution, change and challenges. Routledge, London, pp 94-111 